\title{
Feminism in Carver's Works
}

\author{
Viola Kita \\ PhD Candidate, University of Tirana \\ kitaviola@yahoo.com
}

Doi:10.5901/ajis.2015.v4n1s1p155

\begin{abstract}
The presence of feminism in Carver's work is not studied in depth. The attention is focused on the description of masculine characters while their feminine counterparts have been neglected. In fact, in Carver's female characters can be noticed their strive for freedom and escape which for men is normal but for women can be considered heroic. Carver gives enough space for female characters to develop and show their traits. Therefore, in his work one can see the presence of the topic of gender issues which during the '70s and '80s became the predominant topic of concern. Carver depicts in the female characters those characteristics that embody the favourite topic of the feminists, the "conflict" between masculinity and femininity. His feminism is not perceived in terms of incompatibility and equality but rather on the position, status as well as the role they have in the society. His female characters are really complex. During the second wave of feminism in the United States the attention was focused mainly on middle class women. The same was reflected in Carver's work. Eventually, the working-class people especially women are given a particular significance, which was a novelty for the time.
\end{abstract}

Keywords: feminism, freedom, conflict, masculinity, equality

\section{Introduction to Feminism in Carver's Work}

The presence of women in Raymond Carver's work is significant in understanding the contribution of this writer in the American literature. However, up to now there is no thorough study on this topic. 1

His work can be analyzed under the light of feminist criticism.

While portraying gender, it seems that Carver's work is really close to Hemingway, especially in stories such as "Tell the Women We're Going" or "So Much Water So Close to Home". In these stories, women occupy an insignificant role in Carver's world thus making his work have noticeable masculine characteristics. Women struggle to achieve selfassertion and in doing so they make the society more understandable.

Carver describes with a tremendous accuracy the suffering of women and men alike. In fact, to focus on women means to focus on masculinity as well, because the two cannot stand apart from each other. In fact, by paying attention to the dialogues between men and women we jump to the conclusion that women are more capable in their confrontation with the everyday while men on the other hand are far from the image of the hero, an image that served as a model in Hemingway's masculine characters. Moreover, it seems that some definitions which were held to be true as far as the role of women in society is concerned, seems to be outdated and ungrounded.

Toni and Leo's tragedy in "Are These Actual Miles"-first published in Will You Please Be Quiet, Please? (1976) as "What Is It?" is the best example of the gender dynamics in all of Carver's work. Toni's probable prostitution act to ensure the sale of the convertible car is a symbolic act of the way female's body is "used" by men in our society accompanied of course by the feelings of guilt and remorse.

The suburban domestic atmosphere to which women in Carver's fiction have been confined leaves them trapped in domestic routine. Women lose all sense of identity because they have no opportunity for self-realization.

In Carver's work are portrayed many female characters who challenge the boundaries placed on them by the society. They achieve this by developing strategies that help them. A typical example is the way Olla feels the sensation of the triumph when she shares her house with her husband in "Feathers," affirming that it "can constitute a positive, lifeaffirming space." 2 It is concluded that if men find an escape from confines of the society, they never use that freedom to

1 Nesset, Kirk. "This Word Love': Sexual Politics and Silence in Early Raymond Carver." American Literature 63. 2 (1991): $292-313$.

2 Will You Please Be Quiet, Please? (1976); 
"energize" their lives. However, women though they don't have such a freedom and therefore not having the chance to do anything exceptional, they "find transcendence in the small acts of bravery and honesty that confront them on a daily basis."2

According to Vanessa Hall's "Influences of Feminism and Class on Raymond Carver's Short Stories,3" Carver's sensitivity to the female's state makes them a reflection of the society's discourse on masculinity and femininity" in the $70 \mathrm{~s}$ and $80 \mathrm{~s}$. Based on the feminist discourse of the period, his description of the lives in the home, with no possibility of escape or change becomes a symbol of the depression that results from its monotony. Despite their inferior status women demonstrate a desire to change their status in their lives and thus to become less independent on others which makes them superior to the lethargy found in men in most of Carver's stories. Women become the best representative for the working-class people who struggle to overcome the biographical and socio-cultural obstacles imposed by society. Thus women really start to "influence" the society.

Carver shows his skills as a writer through the portrayal of his female characters. He has proved what social theories have just mentioned that gender identities are produced by the society. The question of masculinity, and how it is represented in Carver's studies, is tackled in Josef Benson's article "Masculinity as Homosocial Enactment in Three Stories by Raymond Carver."3 Benson demonstrates how Carver's work is dominated by male figures who are dependent on other males to prove their masculinity, thus generating homosocial desire.

\section{Women Against Oppression}

Critics like Winfried Fluck have used the term "weak identity" to refer to Carver's characters. This is due to the fact that women do not have the possibility to achieve status and power. The philosopher Julia Kristeva claims that identities are unstable and in order to illustrate her idea she coined the term "subject-in-process". This process refers more to a trial where the identities are called into question. This concept of the "subject-in-process" can be used as a tool for analyzing Carver's female characters. The most typical example is that of the woman in the story "The student's wife" where the woman has to undergo a really painful existence because of the pains in her arms, shoulders and legs. This is the best embodiment of Kristeva's concept of the subject as a wounded body. This concept refers to her psychoanalytical theories on identity and subjectivity. Her idea is to reconstitute her so-called "a wounded narcissistic identity". Her suggestion is as follows: 'heal your inner wounds which as a result will render you then capable of effective social action, or intervention in the social plane with the other". ${ }^{4}$

In one particular moment in the story, we understand her inner fears and pains of becoming a woman. In a moment like this she asks her husband: "Didn't you ever feel yourself growing? Her inner desire is to stop being treated as a child or patient by her abusive husband. This desire becomes obvious when she utters: "I like that, flying in airplanes. There's a moment as you leave the ground you feel whatever happens is all right". This moment can be interpreted as foreshadowing of the future independence of the woman. In the final description of the story:

"When it began to be light outside she got up. She walked to the window.... The trees and the row of two-story apartment houses across the street were beginning to take shape as she watched.... Except for the times she had been up with one or another of the children..., she had seen few sunrises in her life.... By stages things were becoming very visible."

As it can be seen, Carver' character is "a subject-in-process" due to the lack of formation of the identity of the character.

The same ideas are obvious even in the short story "I Could See the Smallest Thing" 5in which the wife can hardly bear the presence of her husband. She suffers from insomnia and in one particular moment she leaves her house in the middle of the night. Upon her return, she states: "I thought for a minute of the world outside my house, and then I didn't have any more thoughts except the thought that I had to hurry up and sleep". Her life is very different from what it ought to be but though she can feel it she cannot do anything to change it. In another story, "Blackbird Pie" 6 it is shown a totally different female character that displays her determinism quite obviously by daring to escape the prison she happened to be because of her marriage contract.

\footnotetext{
3 Vanessa Hall's "Influences of Feminism and Class on Raymond Carver's Short Stories,(1998)

4 "An interview" Julia Kristeva 1996

${ }^{5}$ What We Talk About When We Talk About Love (1981);

6 Where I'm Calling From (1988);
} 
Subjectivity is a key concept in feminist theory. Teresa de Lauretis' uses "eccentric subject" a term used to refer to an "excessive critical position ... attained through practices of political and personal displacement across boundaries between sociosexual identities and communities, between bodies and discourses" ("Eccentric" 182). Her theory is very helpful in analyzing Carver's female characters. In Carver's first collection, once again we encounter women who want to get rid of their husbands who isolate them and make them feel smaller and unimportant but that unfortunately they cannot find the strength and determination to do so.

De Lauretis explains the concept of "the figures of resistance" according to which certain female figures refuse to accept the norms and rules imposed on them by the society. For instance, in the short story "What Do You Do in San Francisco?" the young woman is nothing like the standard of femininity that is perceived by the society. She is portrayed as a woman who wears male clothes by making the people around her feel outrageous and especially neighbours pass all the limits by questioning her devotion and role as a mother and wife. All the speculations are triggered because she refuses to wear what the society considers decent.

Another example of a "figure of resistance" can be found in "Blackbird Pie". In this story the husband cannot accept the fact that his wife has abandoned him and thus constructs a whole theory of secrets and suspicious actions. He bases his theory on the grounds that the handwriting in the letter addressed to him is not that of his wife, and therefore something strange and inexplicable must be going on. The letter becomes a symbol of a figure of resistance because it represents the object that breaks all the norms of the patriarchal law according to which a woman cannot leave her husband. Ironically, women find their force even in a pen.

The same idea is inferred in Carver's poem "The Other Life" in which the husband narrator describes the moment his wife is signing the divorce papers:

"My wife is in the other half of this mobile home making a case against me.

I can hear her pen scratch, scratch. Now and then she stops to weep, then- scratch, scratch."

The verb "scratch" is repeated by making us believe that her writing is disturbing the husband who feels that the patriarchal order is threatened.

\section{Masculinity in Crisis}

"Masculinity in crisis" is interpreted by feminist critics not as a "crisis of manhood," as many believe but as a wrong concept of masculinity in itself. In gender theory, the concepts of 'men' and masculinity are unstable, especially in Carver's stories. Unlike Hemingway's male characters who were strong and heroic, Carver's characters are men who cry, men that feel undecided and consequently bearing everything that is far from the traditional concept of manhood.

In Cathedral the traditional masculinities are long gone, since women become active subjects while men stand as passive objects. The recovering alcoholics in "Where I'm Calling From" or the male protagonists in "Cathedral," are portrayed as men who lack confidence and lead a life characterized by anxiety. On the other hand there are also men who repress their insecurity and remain silenced such as the husband in "Preservation," who is jobless and spends his day on the sofa. These men are so different from the knights who rescued their damsels, as the character of Mel in "What We Talk about When We Talk about Love" dreams of: "... what I liked about knights, besides their ladies, was that they had that suit of armor, you know, and they couldn't get hurt very easy"7 .

In Carver's portrayal of masculinity, the concept of heterosexuality is prevalent. However, some characters are shown in situations and actions that can be interpreted as queer. Teresa de Lauretis coined the phrase "queer theory"( theorizing lesbian and gay sexualities) in 1990 which seems to explain this phenomenon in Carver's stories. One of Carver's stories that could be interpreted by making use of this theory is "Neighbours," in which as Nesset argues, the characters are often "trapped in a kind of sexuality they cannot understand" 8 Bill Miller gets into the neighbors' apartment, a place that William Stull defines as a "psychosexual rumpus room" and abandons himself into what can be called "an impossible queer fantasy".

In a moment, he finishes his drink, takes off his suit, finds and wears a pair of panties and a brassiere. Then he puts on a black and white skirt, zips it up and is about to wear even his wife's shoes if they would fit. Bill's crossdressing performance momentarily turns him into a queer subject. As feminist critic Alice Walker argues: "the cross-

7 "What We Talk about When We Talk about Love", pg (148-149)

${ }^{8}$ De Lauretis, Teresa. "Eccentric Subjects." Figures of Resistance: Essays in Feminist Theory. Ed. 
dresser functions as a disorderly and subversive presence: by resisting assimilation within a system of binary oppositions, he or she reveals the inadequacy of this system, and, furthermore, questions the extent to which appearance and identity are coextensive" .

In fact, Bill's cross-dressing performance, even though it is limited in space and time, reveals queerness, a taboo in traditional masculinity and thus a threat to patriarchy.

In "Cathedral" can be found moments of queer desire where two men, who at first were rivals, find out that they have a lot in common. At first, the reader is introduced to a narrator who continuously underestimates his wife. However, his attention is totally focused on her when he feels threatened when one of his wife's friends decides to visit them. At this particular moment the masculinity crisis appears and feeling inferior he decides to become a friend with his rival. The erotic triangle is created, thus drawing parallels to the feminist theory. In this triangle the bond between the rivals is as strong as the bond between their beloved one. Consequently, the feelings that they experience are of an intense level.

Since it cannot be defined as a real homosexual desire, perhaps it would be much better to refer to the term used by Sedgwick "homosocial desire". ${ }^{10}$ However, there are moments that can be described as homoerotic especially at the end of the story. Let's take into consideration this fragment:

He found my hand, the hand with the pen. ... "Press hard," he said to me. "That's right. That's good," he said. "Sure. You got it, bub. I can tell. You didn't think you could. But you can, can't you? You're cooking with gas now." ... "Don't stop now. Draw." So we kept on with it. His fingers rode my fingers as my hand went over the paper. It was like nothing else in my life up to now. ${ }^{11}$

In another story titled "The Calm", the husband takes the decision to leave his wife while he is in a barber shop:

"We looked into the mirror together, his hands still framing my head. I was looking at my self, and he was looking at me too.... He ran his fingers through my hair. He did it slowly, as if thinking about something else. He ran his fingers through my hair. He did it tenderly, as a lover would".12

As it can Playing with male identification by employing mirrors and metaphors of the double, Carver manages to transform a masculinist scenario where men use toothpicks and discuss violent stories into a place of homoerotic possibility between the barber and the protagonist.

Carver's oeuvre is not concerned with politics, social issues or movements. He does not like ideological abstractions. He is not the kind of writer who proclaims feminism's ideas neither as advocate nor as adversary.

To illustrate Carver's discourse on feminism let us focus on a short story entitled "Fever," a story in which the protagonist, Carlyle, abandoned by his wife Eileen, is confronted to four females belonging to age groups that span three generations: the late adolescent Debbie, whom Carlyle took as a babysitter "in desperation to find someone" the day before resuming his teaching job; Carol, the secretary he works and occasionally has sex with; Eileen, whose absence he is trying to get over; Mrs. Webster, the elderly babysitter he can finally "count on" at the end of the story and whose authenticity of feeling and expression have the maieutic function of helping him express his feelings as well, thus overcoming his crisis and moving on to another phase in his life.

This story has a lot to do with language. The four women are not analyzed in depth psychologically according to the conventions of realism. In fact, each character is portrayed only through the speech type Carver attributes to them. Debbie isn't a good influence for his children, abandoned on the lawn the first day Carlyle comes back from work, while "in the living room with three teenaged boys" and her "blouse...unbuttoned," Debbie's voice is not heard because there is "Rod Stewart screaming from the stereo," a metaphor for the teenage sub-culture that has such a great influence on her.

The phrases used in the story should be read very carefully because they give hints that help the better understanding of the story. For example, the older Carol's "voice," really "sounded indistinct". Her response to Carlyle's story of the incident with Debbie is parodied in the third person: "Did he want her to come over to his place? she asked... He shouldn't be afraid to say when he needed affection, she said". Switching to direct discourse, her speech continues in sentimental phrases that contain no sincerity in them: "Sweetie, I'm sorry about what happened. But I

\footnotetext{
${ }^{9}$ Alice Walker "As you wear: Cross-dressing and Identity politics in Jackie Kay's Trumpet" Journal of International Women's Studies, Volume 8, Feb- 2007

10 Between Men: English Literature and Male Homosocial Desire, Eve Kosofsky Sedgwick; Columbia University Press; 1985

11 "The Calm", "What we talk about when we talk about love"

12 "The Calm", "What we talk about when we talk about love"
} 
understand your wanting to be alone. I respect that.... Honey, don't let it get you down". Influenced by her way of speaking she continues in the same way: "Thanks again for being there when I need you... You're one in a million, you know". However, he does not feel good about what he said. He would have rather said something else and feel much better because at least he would have known that was honest. He'd never talked that way before in his life". It seems that Carlyle was forced to behave and speak in a way that was too sentimental and too unrealistic to the relationship they have with one another. In the end neither Debbie nor Carol, have an identity of their own. Therefore none of them can reflect upon the conditions or the state of females.

If we take into consideration the undeveloped voice of Debbie and the "indistinct" voice of Carol, Eileen's voice, has a certain volume and a vibrato, which aggravated Carlyle's pain instead of soothing or healing it. Though Eileen's language seems sophisticated it is made of stereotypical phrases that are difficult to relate to her, as they also show her discrepancy from the real: "We have to keep all lines of communication open," she tells Carlyle although in fact she never communicates with him or the children. "I think the worst is over. For both of us. I've suffered too". Despite her decision to emancipate herself from them Eileen does not give the impression that she has suffered, and the worst is far from over for Carlyle and the children she left behind.

At the root of all this stands Eileen awakening of her past ambitions to realize herself as an artist: "In college, she had majored in art, and even though she'd agreed to marry him, she had always wanted to do something with her talent. Carlyle said he wouldn't have it any other way. She owed it to herself, he said. She owed it to both of them.... Then, after eight years of being married to him, Eileen had pulled out. She was, she said in her letter, 'going for it"'- "it" being the talent she prioritizes over motherhood: "Tell Keith and Sarah I love them. Tell them I'm sending some more pictures. Tell them that. I don't want them to forget their mother is an artist. Maybe not a great artist yet, that's not important. But, you know, an artist. It's important they shouldn't forget that". She sends them a photograph of herself "in a big, floppy hat, wearing a bathing suit" or "a pencil drawing... of a woman on a riverbank in a filmy gown, her hands covering her eyes, her shoulders slumped. It was, Carlyle assumed, Eileen showing her heartbreak over the situation". Her posture seems to imitate the stereotypical example a female "artist."

According to Bahtin: "The words of a speaking person are always ideologemes, carriers of an ideological discourse rather than neutral, ever registering with extreme subtlety the tiniest shifts and oscillations of the social atmosphere"13. Therefore, Eileen's decision to free herself from her marriage, can be seen as influenced by a certain social climate created by feminist ideology during the 70s and 80s. It is at least suggested in her expression "go for it" as well as in Carlyle's own justification, "she owed it to herself. She owed it to both of them," by encouraging in this way her emancipation toward self-realization that was the core of feminism.

Something that should not be underestimated is their profession. One is a teacher of art and the other is an artist which distinguishes them from the working-class Carol, both Carlyle and Eileen who couldn't feel the movement's force and influence. Carlyle implies, during an art lesson on Byzantine paintings, "he took so long trying to place the anonymous artists in their social milieu that some of his students began to scrape their shoes on the floor, or else clear their throats". The students are feeling impatient because Carlyle's preoccupation is personal and doesn't have to do with the them. On the other hand, in Carol's words one cannot find "ideologemes" to show feminist ideas.

Although there is no obvious connection with feminism it is definitely clear that Eileen embodies emancipation from the domestic sphere. When considering Eileen's responsibilities as a mother it can be said that Carlyle has a more developed 'motherly instinct' than Eileen, who seems to have none, or lost it in the process of emancipation. In the story entitled "Fever" is dealt with the myth of women as having a greater capacity to care for and connect with others, a capacity that is apparently not linked to gender.

In order to refer back to the issue of gender, Carlyle confesses to Mrs. Webster that Eileen was not always the kind of wife and mother she has now become: "Mrs. Webster, there's something I want you to know. For a long time, my wife and I loved each other more than anything or anybody in the world. And that includes the children". He also expresses that even Eileen's voice was different: "He longed to hear her voice-sweet, steady, not manic as it had been for months now..." Etymologically, "manic," from mania 'madness,' connects with maenad, 'bacchante,' which Merriam Webster defines as "an unnaturally excited or distraught woman "illustrating women who left their homes to follow Bacchus in Euripides' eponymic Bacchae, maenad/manic on the other hand is in harmony with Carlyle's frequent repetition of Eileen as "crazy": "She was losing her mind. That much was clear to him". It seems that Eileen is trying to forget the past as well as the present and is only focused on her idea of being an artist.

${ }^{13}$ Bahtin- Literary critic 
Based on what is described above feminism can be made responsible for Eileen's giving up of all commitment to Carlyle and her children, the pain she caused to both of them as well as the change her voice underwent from "sweet, steady" to "manic." However, it shouldn't be inferred that Carver is trying to describe feminism as a reason for destroying marriages. The argument that opposes this misinterpretation stands on the fact that if Carver really wanted to do that he would have ended his story with Eileen rather than with the fourth and last female of Mrs. Webster, as he does.

\section{Conclusions}

It can be concluded that Carver's female characters are a very interesting case of study for all scholars. In them one can sense the search for freedom which due to the given circumstances can be considered heroic. It is heroic because it is developed under the conflict between masculinity and femininity which is as old as the whole world. At the end of it women are the ones to be depicted as those who fought for their position in society while men just had it given as a gift from their birth.

In Carver's work are depicted middle class women, which was a novelty for the fiction of the time. However, Carver is not focused on women only but in fact by paying attention to them he brings to focus masculinity as well because they cannot stand apart from each other. Carver portrays men and women who suffer alike. Especially men who are far from the image of the hero, an image that stands at the center of the work of other great writers like Hemingway. Such a concept in his work is given as outdated and ungrounded.

Some of the topics concerning feminism include the "use" of female body by men as portrayed in the short story "Are these Actual Miles"?, women trapped in the domestic atmosphere as well as the topic of challenging all the boundaries imposed on them by the society. Examples of such topics can be found in stories like "Feathers", "Student's Wife", "I Could See the Smallest Thing".

In addition, Carver's skills as a writer are shown through the portrayal of his female characters. He has proved what social theories have been claiming about gender identities and the influence of the society that produces them. Society can play an active role in the way certain characters are shaped. Philosophers like Julia Kristeva, have used the term "weak identity" to refer to Carver's characters. In order to show how unstable these identities were, Kristeva coined the term "subject-in-process" that became a perfect tool for the analysis of the characters, especially female characters.

Another important concept in the work of Carver is that of subjectivity which is also a key concept in the feminist theory. Teresa de Lauretis has used the term "eccentric subject" to analyze female characters. This is applied especially to that group of women in Carver's stories who simply want to get rid of their husbands. The reason behind this is that their husbands isolate them and make them feel so unimportant. However, it is really painful that despite their desire these women have neither strength, nor determination to do anything.

In contrast, De Lauretis also presents the concept of "the figures of resistance" according to which there is a particular category of women who do not care about the norms of the society but develop their own individuality and do things which are acceptable if we take into consideration the human rights but are shocking to a patriarchal society. This is perfectly depicted in characters such as the woman who wears male clothes in the story "What Do You Do in San Francisco" or in the women who abandon their husbands in the short stories "Blackbird Pie" and "The Other Life".

Finally, it can be said that carver is a master of penetrating in the human soul. He can depict characters in a way nobody else can and he does that with elegance and skill. No other writer can discuss delicate gender issues in such a careful yet straightforward language. All feminist theories are proved in his work filled with characters that know how to shock, move or even identify with you. Perhaps, feminist activists must study his work in depth and acknowledge the great contribution Carver has given not only to World Literature but to their cause as well.

\section{References}

Carver, Raymond. "Blackbird Pie." Elephant and Other Stories. London: Vintage, 2003 (1988)

"Careful." Cathedral. London: Vintage, 2003 (1983).

"Cathedral." Cathedral. London: Vintage, 2003 (1983).

"Fat." Will You Please Be Quiet, Please? London: Vintage, 2003 (1973).

"I Could See the Smallest Things." What We Talk About When We Talk About Love. New York: Vintage, 1989 (1974).

"Neighbours." Will You Please Be Quiet, Please? London: Vintage, 2003 (1973).

"One More Thing." What We Talk About When We Talk About Love. New York: Vintage, 1989 (1974).

"The Calm." What We Talk About When We Talk About Love. New York: Vintage, 1989 (1974).

"The Other Life." All of Us: The Collected Poems. New York: Vintage, 2000. 
"The Student's Wife." Will You Please Be Quiet, Please? London: Vintage, 2003 (1973)..

"What Do You Do in San Francisco?" Will You Please Be Quiet, Please?London: Vintage, 2003 (1973).

"What We Talk About When We Talk About Love." What We Talk About When We Talk About Love. New York: Vintage, 1989 (1974).

"Will You Please Be Quiet, Please?" Will You Please Be Quiet, Please?London: Vintage, 2003 (1973).

De Lauretis, Teresa. "Eccentric Subjects." Figures of Resistance: Essays in Feminist Theory. Ed.

Kristeva, Julia. An Interview with Julia Kristeva. Conducted by Kathleen O'Grady.

Powers of Horror: An Essay on Abjection. New York: Columbia University Press, 1982.

"A Question of Subjectivity. An Interview." Modern Literary Theory: A Reader.Eds. Philip Rice and Patricia Waugh. London and New York: Edward Arnold, 1989:128-134.

Nesset, Kirk. "This Word Love': Sexual Politics and Silence in Early Raymond Carver." American Literature 63. 2 (1991): $292-313$.

Rich, Adrienne. "The Knight." Snapshots of a Daughter-in-law: Poems, 1954-1962. New York: Harper and Row, 1963.

Russo, Mary. "Female Grotesques: Carnival and Theory." Feminist Studies/Critical Studies. Ed. Teresa de Lauretis. London: Macmillan, 1988:213-229.

Sedgwick, Eve Kosofsky. Between Men: English Literature and Male Homosocial

Desire. New York: Columbia University Press, 1985.

Silverman, Kaja. Male Subjectivity at the Margins. New York: Routledge, 1992. Stull, William L. "Raymond Carver." Dictionary of Literary Biography: Yearbook,1988. Ed. J. M. Brook. Detroit: Gale, 1988.

Walker, Alice. "As You Wear: Cross-dressing and Identity Politics in Jackie Kay's

Trumpet." Journal of International Women's Studies 8.2 (February 2007): 35-43.White, Patricia. "Introduction." Figures of Resistance: Essays in Feminist Theory.

Urbana and Chicago: University of Illinois Press, 2007: 1-22.

Table 2: Existence of unethical practices

\begin{tabular}{|c|c|c|c|c|c|c|c|}
\hline & \multirow{2}{*}{ All (\%) } & \multicolumn{2}{|c|}{ Company Size } & \multicolumn{4}{c|}{ Management Position } \\
\cline { 3 - 8 } & & SMEs (\%) & Large (\%) & Top (\%) & Upper - middle (\%) & Lower - middle (\%) & Other (\%) \\
\hline None & 15.0 & 15.8 & 13.6 & 23.1 & 10.5 & 10.5 & 22.2 \\
\hline Yes, a few & 61.7 & 63.2 & 59.1 & 61.5 & 63.2 & 63.2 & 55.6 \\
\hline Yes, many & 16.7 & 21.1 & 9.1 & 15.4 & 21.1 & 10.5 & 22.2 \\
\hline Don't know & 6.7 & 0.0 & 18.2 & 0.0 & 5.3 & 15.8 & 0.0 \\
\hline
\end{tabular}

$N=60$.

Table 3: Unethical practices most wanted to eliminate

\begin{tabular}{|l|c|c|c|}
\hline & All (\%) & SMEs & Large \\
\hline Giving of gifts, gratuities, and briberies & 53.2 & 50.0 & 60.0 \\
\hline Price discrimination and unfair pricing & 46.8 & 50.0 & 40.0 \\
\hline Dishonesty in making or keeping a contract & 42.6 & 40.6 & 46.7 \\
\hline Miscellaneous unfair competitive practices & 42.6 & 46.9 & 33.3 \\
\hline Price collusion by competitors & 27.7 & 28.1 & 26.7 \\
\hline Cheating customers & 27.7 & 31.3 & 20.0 \\
\hline Dishonest advertising & 23.4 & 25.0 & 20.0 \\
\hline Unfairness to employees & 21.3 & 18.8 & 26.7 \\
\hline Overselling & 12.8 & 18.8 & 0.0 \\
\hline Unfair credit practices & 10.6 & 12.5 & 6.7 \\
\hline Other and unspecified & 4.3 & 3.1 & 6.7 \\
\hline
\end{tabular}

$N=47$. The question was designed as multiple-choices type, the respondents were asked to check as many answers as applicable. Percentage among those who answered this question.

Table 4: Company efforts to build ethical values into organization

\begin{tabular}{|c|c|c|c|c|c|c|c|}
\hline & \multirow{2}{*}{ 2All (\%) } & \multicolumn{2}{|c|}{ Company Size } & \multicolumn{4}{|c|}{ Management Position } \\
\hline & & SMEs (\%) & Large (\%) & Top (\%) & Upper - middle (\%) & Lower - middle (\%) & Other (\%) \\
\hline Yes, very eagerly & 13.6 & 10.8 & 18.2 & \multirow{2}{*}{46.2} & \multirow{2}{*}{66.7} & \multirow{2}{*}{63.2} & \multirow{2}{*}{66.7} \\
\hline Yes, to some extent & 47.5 & 40.5 & 59.1 & & & & \\
\hline Yes, but very little & 13.6 & 18.9 & 4.5 & 30.8 & 5.6 & 10.5 & 11.1 \\
\hline Not at all & 25.4 & 29.7 & 18.2 & 23.1 & 27.8 & 26.3 & 22.2 \\
\hline
\end{tabular}

$N=59$. 
Table 5 Panel A: Methods of building ethical values into the organization

\begin{tabular}{|l|c|c|c|}
\hline & \multirow{2}{*}{ All (\%) } & \multicolumn{2}{|c|}{ Company Size } \\
\cline { 3 - 4 } & & SMEs (\%) & Big (\%) \\
\hline Corporate philosophy including ethics & 86,4 & 80,8 & 94,4 \\
\hline Code of ethics & 45,5 & 34,6 & 61,1 \\
\hline Contribution to social/cultural activity & 43,2 & 34,6 & 55,6 \\
\hline Punishment for unethical conduct & 34,1 & 23,1 & 50,0 \\
\hline Employee training in ethics & 27,3 & 15,4 & 44,4 \\
\hline CEO's frequent statements on ethics & 18,2 & 23,1 & 11,1 \\
\hline Following parent company's philosophy & 18,2 & 15,4 & 22,2 \\
\hline Anonymous Reporting Hotline for unethical conduct & 11,4 & 3,8 & 22,2 \\
\hline Suggestion system on ethics & 6,8 & 0,0 & 16,7 \\
\hline Ombudsman & 6,8 & 3,8 & 11,1 \\
\hline Social auditing & 6,8 & 7,7 & 5,6 \\
\hline Ethics committee & 0,0 & 0,0 & 0,0 \\
\hline Other and unspecified & 0,0 & 0,0 & 0,0 \\
\hline
\end{tabular}

Table 5 Panel B: Average number of ethical enhancement tools for SMEs and large companies by management position

Top management Upper middle management Lower middle management Other

\begin{tabular}{|c|c|c|c|c|c|}
\hline \multirow[t]{2}{*}{ ALL } & SMES & Large & All & SMES & Large \\
\hline & & & 2.6 & 1.6 & 5.0 \\
\hline \multirow{3}{*}{3.0} & 0 & $?$ & 2.9 & 2.4 & 4.3 \\
\hline & 2.4 & 3.9 & 3.2 & 3.3 & 3.1 \\
\hline & & & 3.7 & 2.5 & 4.3 \\
\hline
\end{tabular}

$N=44$.

Table 6: Company responsible to social groups (mean ranks)

\begin{tabular}{|c|c|c|c|}
\hline & All & SMEs & Large \\
\hline Customers & 1.7 & 1.4 & 2.1 \\
\hline Employees & 2.8 & 2.6 & 3.1 \\
\hline Stockholders & 3.0 & 3.3 & 2.6 \\
\hline Suppliers & 4.3 & 4.1 & 4.7 \\
\hline Society in general & 4.4 & 4.6 & 4.1 \\
\hline Government & 6.1 & 6.8 & 5.1 \\
\hline Dealer & 6.3 & 6.1 & 6.7 \\
\hline Local community & 6.4 & 6.3 & 6.6 \\
\hline
\end{tabular}

$N=58$. Number 1: social group to which respondents feel most responsible, $n$. 8: social group to which respondents feel least responsible.

Table 7: Experience of conflicts between company interests and personal ethics

\begin{tabular}{|c|c|c|c|c|c|c|c|}
\hline & \multirow{2}{*}{2 All (\%) } & \multicolumn{2}{|c|}{ Company Size } & \multicolumn{4}{c|}{ Management Position } \\
\cline { 3 - 8 } & & SMEs (\%) & Large (\%) & Top (\%) & Upper - middle (\%) & Lower - middle (\%) & Other (\%) \\
\hline Yes & 50.8 & 55.3 & 42.9 & 38.5 & 52.6 & 50.0 & 66.7 \\
\hline No & 49.2 & 44.7 & 57.1 & 61.5 & 47.4 & 50.0 & 33.3 \\
\hline
\end{tabular}

$N=59$.

Table 8: Issues with regard to which conflicts between company interests and personal ethics were experienced

\begin{tabular}{|c|c|}
\hline & All (\%) \\
\hline \multicolumn{2}{|l|}{ With regard to } \\
\hline \begin{tabular}{l|l} 
& Honestly in internal communication \\
\end{tabular} & 50.0 \\
\hline Gifts, entertainment, and kickbacks & 36.7 \\
\hline Firings and layoffs & 36.7 \\
\hline Honesty in executing contracts and agreements & 30.0 \\
\hline
\end{tabular}




\begin{tabular}{|c|l|c|}
\hline & Fairness and discrimination & 26.7 \\
\hline & Honesty in external communication & 26.7 \\
\hline & Price collusion and pricing practices & 16.7 \\
\hline & Other and unspecified & 3.3 \\
\hline
\end{tabular}

$N=30$.

Table 9: Social groups with regard which ethical conflicts were experienced

\begin{tabular}{|c|c|c|}
\hline & & All $(\%)$ \\
\hline \multicolumn{3}{|c|}{ With regard to } \\
\hline & Suppliers & 48.4 \\
\hline & Employees & 41.9 \\
\hline & Customers & 32.3 \\
\hline & Colleagues & 29.0 \\
\hline & Competitors & 25.8 \\
\hline & The law and government & 22.6 \\
\hline & Superiors & 16.1 \\
\hline & Society in general & 3.2 \\
\hline & Other and unspecified & 3.2 \\
\hline & Stockholders & 0.0 \\
\hline
\end{tabular}

$N=31$.

Table 10: Have respondents reported unethical practices?

\begin{tabular}{|c|c|}
\hline & All (\%) \\
\hline Yes & 26.3 \\
\hline No & 73.7 \\
\hline
\end{tabular}

$N=57$.

Table 11: Why were not unethical practices reported?

\begin{tabular}{|l|c|}
\hline & All (\%) \\
\hline It was difficult to decide whether the practices were ethical or not & 20.6 \\
\hline Even if reported, it would be difficult to correct the unethical practice & 23.5 \\
\hline It was questionable whether my identity as the person who reported the unethical practice would be kept secret & 17.6 \\
\hline I would receive negative judgment from my superior or colleagues & 0.0 \\
\hline Other & 11.8 \\
\hline
\end{tabular}

$N=34$.

Table 12: Factors influencing ethical decisions (mean ranks)

\begin{tabular}{|l|c|c|c|}
\hline & All & SMEs & Large \\
\hline One's personal code of behaviour & 1.9 & 2.1 & 1.6 \\
\hline Company policy & 2.3 & 2.1 & 2.4 \\
\hline The behaviour of one's superiors & 2.7 & 2.8 & 2.6 \\
\hline The behaviour of one's equals in the company & 3.7 & 3.4 & 3.9 \\
\hline Ethical climate of the industry & 4.3 & 4.1 & 4.5 \\
\hline
\end{tabular}

$N=58$. Number 1 the most influential factor, $n .5$ the least influential factor.

Table 13: Factors influencing unethical decisions (mean ranks)

\begin{tabular}{|l|c|c|c|}
\hline & All & SMEs & Large \\
\hline One's personal financial needs & 2.4 & 2.3 & 2.5 \\
\hline Company policy or lack thereof & 2.7 & 2.8 & 2.5 \\
\hline The behaviour of one's superiors & 2.8 & 2.9 & 2.5 \\
\hline The behaviour of one's equals in the company & 3.3 & 3.4 & 3.2 \\
\hline Ethical climate of the industry & 3.7 & 3.4 & 4.1 \\
\hline
\end{tabular}

$N=58$. Number 1 the most influential factor, $n .5$ the least influential factor. 
Table 14: Hypothetical situations

\begin{tabular}{|l|c|c|}
\hline \multicolumn{1}{|c|}{} & Oneself (\%) & Average manager (\%) \\
\hline Situation 1 (N = 49) & & \\
\hline Acceptable if other executives in the company do the same thing & 5.1 & 31.6 \\
\hline Acceptable if the executive's superior knows about it and says nothing & 27.1 & 40.4 \\
\hline Unacceptable regardless of the circumstances & 67.8 & 28.1 \\
\hline Situation 2 (N = 49) & & 96.6 \\
\hline Probably would & 79.7 & 3.4 \\
\hline Probably would not & 20.3 & 5.3 \\
\hline Situation 3 (N = 48) & 37.9 & 33.3 \\
\hline Refuse to pay, even if sale is lost & 8.6 & 61.4 \\
\hline Pay the fee, feeling it was ethical in the moral climate of the foreign nation & 53.4 & \\
\hline Pay the fee, feeling it was unethical but necessary to help insure the sale & & 7.0 \\
\hline Situation 4 (N = 49) & 15.3 & 22.8 \\
\hline $\begin{array}{l}\text { Issue an order stopping future payments and reduce salespeople's pay in the amount } \\
\text { equal to their commissions on the sales gained as a result of future payments }\end{array}$ & 59.3 & 70.2 \\
\hline Issue an order stopping future payments, but do not reduce sales people's pay & 25.4 & \\
\hline Say and do nothing & & \\
\hline
\end{tabular}

In relation to hypothetical situations, respondents were asked the following questions:

Situation 1: An executive earning EUR 100,000 a year has been padding his expense account by about EUR 5,000 a year. What do you think?

Situation 2: Imagine that you are the president of a company in a highly competitive industry. You learn that a competitor has made an important scientific discovery which will give him an advantage that will substantially reduce the profits of your company for about a year. If there were some hope of hiring one of the competitor's employees who knew the details of the discovery, what would you do?

Situation 3: The minister of a foreign nation, where extraordinary payments to lubricate the decision-making machinery are common, asks you, as a company executive, for an EUR 250,000 (about 6,250,000 CZK) consulting fee. In return, he promises special assistance in obtaining a 100 million EUR (2. bil CZK) contract which should produce, at least, a 5 million EUR (125 mil CZK) profit for your company.

Situation 4: Imagine that you are a regional sales manager for a large industrial supply company and your salespeople are giving money to purchasing agents to obtain sales. This is beyond the generally acceptable meal or promotional item. Assuming that no laws are being violated, what would you do? 